\title{
Ethnocultural influences for zoonoses transmission in multi-ethnic communities in Nepal
}

\author{
Kosh Bilash Bagale'; Ramesh Adhikari; Devaraj Acharya ${ }^{3 *}$; \\ Basant Gaire4; Bidhusi Pokhrel ${ }^{5}$
}

${ }^{1}$ Graduate School of Education, (PhD Scholar) TU., Kirtipur, Kathmandu

${ }^{2}$ Mahendra Ratna Campus, Tribhuvan University

${ }^{3}$ Bhairahawa Multiple Campus, Tribhuvan University

${ }^{4}$ Health Officer, Tokha Municipality, Kathmandu

${ }^{5}$ House Officer, Hospital for Advanced Medical and Surgery, Dhumbarahi, Kathmandu

*Correspondence: drabmc@gmail.com; ORCID: 0000-0003-0847-4836.

\begin{abstract}
Animals contribute to a pivotal role in human societies. Occupational exposure to animals is barred in several ethnicities in Nepal. Limited studies have been found on zoonoses-related diseases and their knowledge, practices, and perception regarding ethnic groups. This study aims to identify the associated factors for human closeness to animals and their host characteristics related to ethnocultural practices. A total of 20 articles were reviewed. In addition to the review, 25 people from different ethnic groups were interviewed. The ethnomedicinal practice and host characteristics of animals for various zoonoses were reviewed from published papers and database journals. There are 1415 species identified as pathogenic to humans, $61 \%$ categorized as zoonotic, and of the 175 newly emerging pathogens, $75 \%$ are listed as zoonoses. Almost all studies among ethnic groups in Nepal revealed that people interact closely with animals for several reasons, including cultural, religious, and ethnomedical practices. Most of the domesticated animals are also possible hosts for the transmission of zoonoses. So, creating awareness about preventing zoonoses is crucial for the protection of the human race. These findings call for immediate action by government and policymakers to control prevalent zoonoses by commencing proactive activities among at-risk groups.
\end{abstract}

Keywords: Diversified communities, ethhno-culture, ethnic group, ethno-medicine, zoonoses

\section{INTRODUCTION}

The history of human civilization started from the commune system. During ancient times, humans depended on the flesh of wild animals to combat hunger. Gradually, civilization and socialization led to well-developed societies with the settlement of the human race through farming and building shelters to house animals (e.g., cattle). They struggled to manage their food, shelter, and well-being through agro and livestock farming (Green News, 2021). 
Animals have special and vague roles in society; people worship and sacrifice animals, make them friends, use them for works and security, kill them, love to watch them, and eat them (Berger, 1980). Animals are part of human life in almost all societies, either in developed and developing countries (Bagale \& Adhikari, 2019). The human-animal relationship has found a long history. In the great Hindu epic Mahabharat, we found that Yudhisthir, the great follower of truth, kept the dog with strange love and responsibilities, which he proved during his journey to Heaven (Bagale, Gaire, \& Adhikari, 2020).

Nepal has a glorious history with diverse cultures among diversified ethnicities. Their culture reflects their daily life. Food habits, clothing, health-seeking behaviors, housing, livestock raising, agro farming, and harvesting are always attributed to their culture. However, those practices need to be safe from the perspective of health and well-being. Nepal also has multiethnic and multi-linguistic communities. According to the National Population and Housing census 2011, 126 castes/ ethnic groups and 92 different linguistic followers in Nepal (CBS, 2011). Most of the ethnic practices and cultures are bonded by their tradition. Since Nepal is an agrarian country, the primary occupation for the living of about sixty-six percent of people is agriculture and livestock farming (Adhikari, 2015).

Animals are an inevitable part of human life; however, due to people's illiteracy and ignorance, they do not know that animals can also act as the source of zoonoses, some are amplifier hosts of many lethal pathogens, also playing a role in transmission as a healthy or asymptomatic carrier (Bagale \& Adhikari, 2019). Due to illiteracy and strong ethnocultural taboo, people face several zoonotic ailments caused by human animals' interfaces. Human societies have used animals for multiple purposes, as highly nourishing food (good protein or sources of vitamins), as means of transport, or as guards in their households. Similarly, some species of animals are used by different ethnicities throughout the countries for the healing of several human illnesses. However, we need to discuss the crucial things, have animals always been beneficial to us? Do we need to take some precautions or safety during the exposure or close contact with them? These are some shadowed or ignored and unanswered questions, especially in underprivileged communities like those in Nepal. So, researchers try to explore the type of ethnocultural and ethnomedical practices practiced by different ethnic groups in Nepal. Moreover, the study aims to identify the animals responsible for the source and host for common zoonoses with references to ethnic groups.

\section{MATERIALS AND METHODS}

This article is based on both primary data and secondary sources. We reviewed the published documents related to our topic from Google Scholar, PubMed, and Bio-Med databases using the search terms, like, ethnocultural, ethnomedicine, culture and zoonoses, host for zoonoses, etc. Similarly, qualitative data were obtained from different ethnic people in study districts by the purposive sampling technique, which might provide cultural and religious values of animals in diversifying ethnic communities of Nepal. The study used a descriptive qualitative dominated multimethod approach to identify the associated factors related to culture and zoonoses.

\section{Population and sample size}

People who have basic knowledge about the animals' use in their religious and socio-cultural practices in Manang, Tanahun and Nawalpur districts (considering at least a district from the geographical region: Mountain, Hill and Terai) of Nepal was the population and samples of 25 different ethnic groups such as; Brahman, Chhetri, Thakuri, Sanyasi, Kami, Sarki, Damai, 
Newar, Gurung, Magar, Thakali, Kumal, Majhi, Bote, Bhujel, Dharai, Tharu, Musahar, Tamang, Sherpa, Rai, Lambu, Teli, Sauka and Chepang were purposively selected.

\section{Inclusion criteria}

Article related to socio-cultural and ethnomedical values of different types of animals in several ethnic groups, animals' host characteristics for several zoonoses in human societies, and articles published in the English language since 1980 till now were included. Based on the above criteria, 35 abstracts were reviewed, with 25 full texts assessed and 20 papers included in the final analysis. Identification and selection of eligible studies

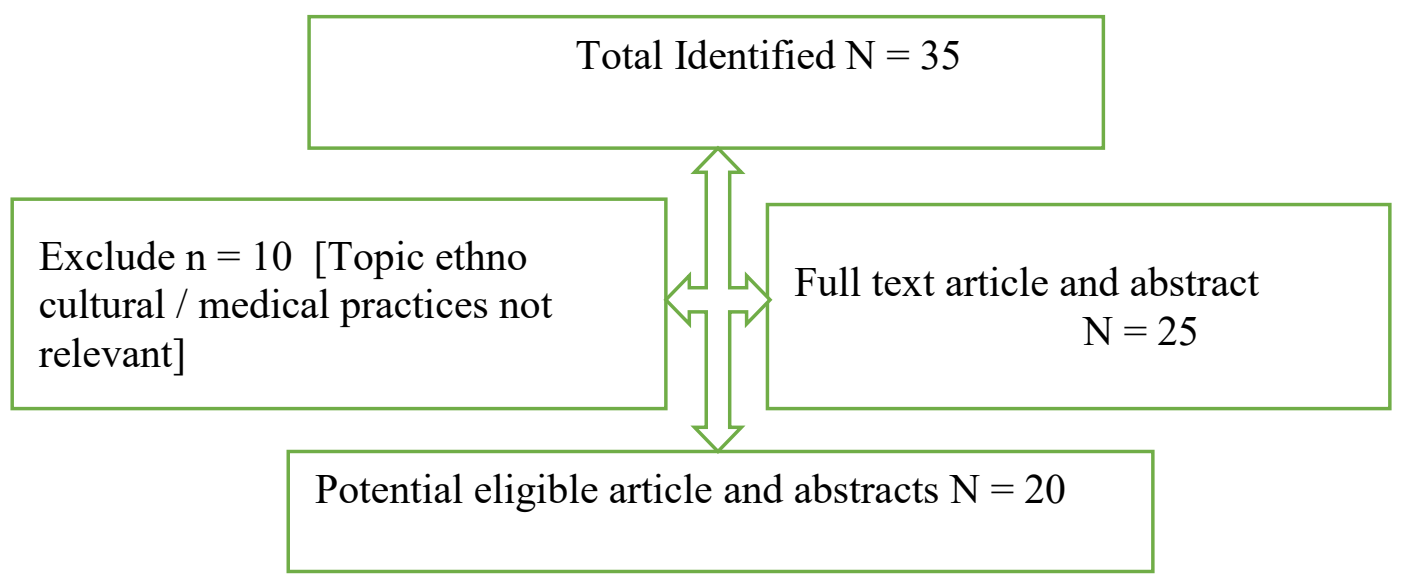

Figure 1. Identification and selection of eligible studies

\section{Exclusion criteria}

Articles other than the English language, articles that are not relevant to animals' cultural and ethnomedical importance, and articles not about zoonotic diseases and case reports were excluded.

\section{Data collection tools and techniques}

Primary data were collected by applying the interview schedule, which incorporates questionnaires related to animals' socio-cultural and religious values in their ethnic societies, and secondary data from multiple databases using related search terms. Descriptive analysis was done with a table on quantitative data, and descriptions with text were used for qualitative data analysis.

\section{Ethical considerations}

During the primary data collection, researchers maintained ethical standards. Consent was taken before the interview, and informants were requested to participate voluntarily. All data were kept confidential with anonymity. Moreover, we followed the ethical guidelines made by the American psychological Association throughout the research process. 


\section{RESULTS}

\section{Status of ethnic groups in Nepal}

The latest national census shows that there were 126 castes and ethnic groups in Nepal. Chhetri is the largest caste/ethnic groups having $16.6 \%$ of the total population followed by Hill Brahman 12.2\%; Magar 7.1\%; Tharu 6.6\% Tamang 5.8\%, Newar 5\%, Kami 4.8\%, Musalman 4.4\%, Yadav 4\%, Rai 2.3\%, Gurung 1.97\%, Damai/ Dholi 1.78\%, Thakuri 1.61\%, Limbu $1.46 \%$, Sarki $1.41 \%$, Teli $1.40 \%$, Chamar $1.27 \%$, Kushwaha Kshatriya $1.16 \%$ and other 108 caste/ ethnic groups represent below one percentage of the $(26,494,504)$ total population (CBS, 2011).

\section{General characteristics of the respondents}

The study included 25 respondents gathered by purposive sampling technique from Manang, Tanahun, and Nawalpur districts. Among the respondents, 14 (56\%) from Tanahun, 9 (36\%) from Nawalpur, and only $2(8 \%)$ were from Manang, and some of the respondents were there for business and public services. Based on gender, $76 \%$ of respondents were male, and single respondents were selected from a single ethnicity/caste.

The diversified ethnic groups followed several socio-cultural practices in their communities. However, most of these practices depend on animals and their by-product for worship, sacrifice, or several cultural celebrations. "Rupa was an active labor but was not able to give birth. Her mother-in-law prayed to Goddess Durga by sacrificing a black goat, sometime after which she delivered the baby" (belief of a Newari woman in Tanahun). Like this example, traditionally, most people in Nepal pray to God and sacrifice animals during adversities. Our primary data shows that most Nepalese people follow the Hindu religion. They sacrifice animals in several religious and cultural ceremonies. However, none have clear ideas about zoonoses transmitted by these animals and their public health implications. Some conveniently selected ethnic people disclosed their practices where animals are required for several cultural purposes.

Table 1: Socio-cultural aspects of animals by different ethnic groups in Nepal

\begin{tabular}{llll}
\hline Ethnic groups & Sociocultural practices & $\begin{array}{l}\text { Name of } \\
\text { animal }\end{array}$ & $\begin{array}{l}\text { The applicable } \\
\text { part of an animal }\end{array}$ \\
\hline $\begin{array}{l}\text { Brahmin, Chhetri Thakuri, } \\
\text { Sanyasi/Dasnami, } \\
\text { Newar }\end{array}$ & $\begin{array}{l}\text { Worship the Goddess Durga } \\
\text { in Dashain. }\end{array}$ & $\begin{array}{l}\text { Goat } \\
\text { hen, buffalo }\end{array}$ & $\begin{array}{l}\text { Head and blood of } \\
\text { the goat }\end{array}$ \\
\hline $\begin{array}{l}\text { Brahmin, Chhetri Thakuri, } \\
\text { Sanyasi/Dasnami, }\end{array}$ & In Tihar & $\begin{array}{l}\text { Cow, crow, } \\
\text { dog, ox } \\
\begin{array}{l}\text { Newar Dalit in Hill (Kami, } \\
\text { Bote, Bhujel, Darai, }\end{array}\end{array}$ & $\begin{array}{l}\text { Worship the live } \\
\text { cow, crow, dog, } \\
\text { and ox }\end{array}$ \\
\hline $\begin{array}{l}\text { Magar, Kumal/ Majhi/ Bote, } \\
\text { Bhujel, Darai, Dalit in Hill, } \\
\text { Chepang }\end{array}$ & $\begin{array}{l}\text { Worship in Dashain, Kul } \\
\text { Puja, Bhakal Puja }\end{array}$ & $\begin{array}{l}\text { Pig, goat, } \\
\text { poultry, buffalo }\end{array}$ & $\begin{array}{l}\text { Blood, head, and } \\
\text { meat }\end{array}$ \\
\hline $\begin{array}{l}\text { Gurung (in Hindu) } \\
\text { Tamang (In Hindu) }\end{array}$ & $\begin{array}{l}\text { Worship in Dashain, Kul } \\
\text { Puja, Bhakal Puja }\end{array}$ & $\begin{array}{l}\text { Goat, poultry, } \\
\text { buffalo, } \\
\text { Sheep }\end{array}$ & $\begin{array}{l}\text { Blood, head, and } \\
\text { meat }\end{array}$ \\
\hline $\begin{array}{l}\text { Thakali } \\
\text { Local cultural festival (twice }\end{array}$ & $\begin{array}{l}\text { Yak } \\
\text { a year, April and August) }\end{array}$ & $\begin{array}{l}\text { Tradition (Raw } \\
\text { blood is good for } \\
\text { health) }\end{array}$ \\
\hline
\end{tabular}




\begin{tabular}{llll}
\hline Sherpa & Local cultural festival & Yak & $\begin{array}{l}\text { Cooked blood for } \\
\text { good health }\end{array}$ \\
\hline Rai/ Limbu & $\begin{array}{l}\text { The naming ceremony, } \\
\text { Marriage, Uddhauli, Kul } \\
\text { Puja, Bhimsen Puja, Prakriti } \\
\end{array}$ & $\begin{array}{l}\text { Hen, pig, } \\
\text { buffalo }\end{array}$ & Meat, egg, blood \\
& Puja & \\
\hline Tharu, Teli, Byansi / Sauka & Worship in Dashain, & Goat, pigeon & Blood, head, meat \\
& $\begin{array}{l}\text { Naming, marriage } \\
\text { ceremony, Kul Puja, Bhakal } \\
\end{array}$ & & \\
& $\begin{array}{l}\text { Puja } \\
\text { Tihar and other cultural, } \\
\text { religious ceremony }\end{array}$ & Cow & Milk, urine, dung \\
& & & \\
\hline
\end{tabular}

(Source: Filed survey, 2020)

Table 1 shows the several socio-cultural practices practiced by different caste/ ethnic groups in Nepal. Ethnic people worship and sacrifice the animals which they consume in different forms or products.

Ethno-medicinal practices of animals and their by-product (Table 2) and wild animals are also equally used, incurring several human illnesses.

Table 2: Ethno medical practices with animals in Nepal

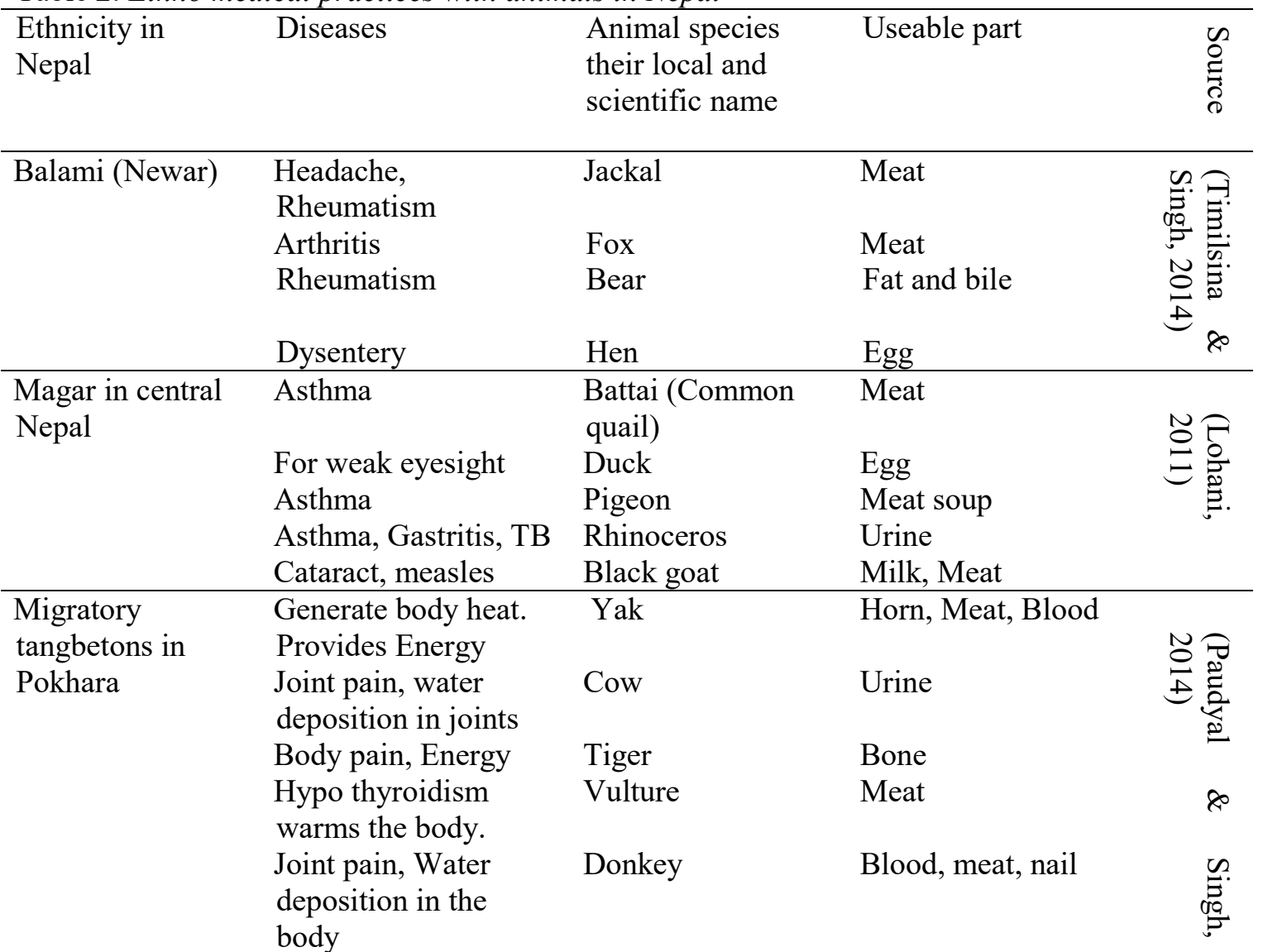




\begin{tabular}{|c|c|c|c|c|}
\hline & $\begin{array}{l}\text { Eye Pain, } \\
\text { Conjunctivitis }\end{array}$ & Human & Urine & \\
\hline \multirow{7}{*}{$\begin{array}{l}\text { Lapcha (Eastern } \\
\text { Nepal) }\end{array}$} & Boil, Asthma & Buffalo & Tooth. Bile & \\
\hline & Mushroom poisoning & Deer & Hoof and fetus & $\vec{\square}$ \\
\hline & Rabies & Dog & Brain & 5 \\
\hline & Rheumatism and TB & Jackal & Meat, bone, hide & $\underbrace{\infty a}$ \\
\hline & Internal eczema & Elephant & Bone & \\
\hline & Cut wound & Snake & Bile & \\
\hline & Burnt wound & Fish & Fat & $\notin$ \\
\hline \multirow[t]{7}{*}{$\begin{array}{ll}\text { Jirel } & \text { (Central } \\
\text { Nepal) } & \end{array}$} & $\begin{array}{l}\text { Improve memory and } \\
\text { sexual power }\end{array}$ & Sparrow & Meat & e \\
\hline & Heart problem & Danphe & Stool & 율 \\
\hline & Asthma & Porcupine & Alimentary canal & E. \\
\hline & $\begin{array}{l}\text { Malaria, jaundice, } \\
\text { heart problem, gout }\end{array}$ & Bear & Bile juice & $\stackrel{N}{\circ}$ \\
\hline & Sprain, Burn, wound & & Fat & \\
\hline & Antidote to poisoning & Black dog & Stool & \\
\hline & For rapid hair growth & Bat & Cooking oil & \\
\hline \multirow[t]{2}{*}{$\begin{array}{l}\text { Tamang in central } \\
\text { Nepal }\end{array}$} & $\begin{array}{l}\text { Improve the eyesight, } \\
\text { Cure even cancerous } \\
\text { wounds. }\end{array}$ & $\begin{array}{l}\text { Any species of } \\
\text { snake }\end{array}$ & $\begin{array}{l}\text { Meat } \\
\text { Fat from cooked } \\
\text { snake }\end{array}$ & 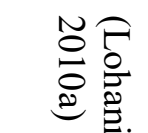 \\
\hline & Bile juice & Buffalo & $\begin{array}{l}\text { Gastritis } \\
\text { Typhoid fever }\end{array}$ & \\
\hline \multirow[t]{4}{*}{ Darai in Chitwan } & Egg & Huttityan (Bird) & Typhoid & $\tilde{0} \mathscr{\theta}$ \\
\hline & Bone & Vulture & Fracture & 票号 \\
\hline & Bone & Peacock & Heart pain & $=\sqrt{0}$ \\
\hline & Urine, sweat & Horse & $\begin{array}{l}\text { Alcohol addiction, } \\
\text { typhoid }\end{array}$ & $\infty$ \\
\hline \multirow[t]{7}{*}{ Majhi } & Cooked flesh & $\begin{array}{l}\text { Nilkantha /Theuwa } \\
\text { (Bird) }\end{array}$ & Anti-oxitic & 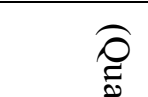 \\
\hline & Blood and bile & Deer & Infertile women & 文 \\
\hline & Urine & Sheep & $\begin{array}{l}\text { Anti-otitis } \\
\text { (earache) }\end{array}$ & 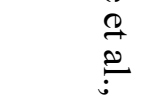 \\
\hline & Bile & Sloth Bear & Anti-hydrocele & ¿ \\
\hline & Urine & $\begin{array}{l}\text { (Indian } \\
\text { Rhinoceros) }\end{array}$ & $\begin{array}{l}\text { Heal for sick } \\
\text { livestock }\end{array}$ & e \\
\hline & Liver, gall bladder & Monkey & $\begin{array}{l}\text { Good for TB } \\
\text { patients }\end{array}$ & \\
\hline & Bile & Asian elephant & Anti-gastritis & \\
\hline Sherpa & Cooked blood & Yak & $\begin{array}{l}\text { For a healthy body, } \\
\text { Gastritis, } \\
\text { hypertension }\end{array}$ & 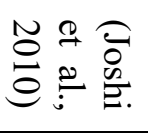 \\
\hline
\end{tabular}

Animals are important reservoirs for numerous pathogens. These pathogens are transmitted to humans. There are different types of zoonotic agents (Table 3) that are responsible for many human illnesses. 
Table 3: Animals and their host characteristics for different zoonoses

\begin{tabular}{|c|c|c|}
\hline Name of the animals & Causative agent & Possible host for \\
\hline $\begin{array}{l}\text { Dog, wolf, jackal, mongoose, bat } \\
\text { (canine groups) }\end{array}$ & Rabies virus & Rabies \\
\hline Cats and their families & Parasite Toxoplasma gondii & Toxoplasmosis \\
\hline $\begin{array}{l}\text { Dogs, rodents, and farm animals. } \\
\text { (Wild and domestic) }\end{array}$ & $\begin{array}{l}\text { Bacteria of the Genus } \\
\text { Leptospira }\end{array}$ & Leptospirosis \\
\hline Poultry (Avian) and birds & H5N1 virus & Avian influenza \\
\hline $\begin{array}{l}\text { Avian (chicks \& duckling) cattle, } \\
\text { livestock, and reptiles }\end{array}$ & Salmonella bacteria & Salmonellosis \\
\hline Cow, buffalo (Livestock and cattle) & Mycobacterium Bovis & Bovine TB \\
\hline Goat, sheep (cattle/ buffalo) & $\begin{array}{l}\text { Brucella spp., intracellular, } \\
\text { gram-negative coccobacilli }\end{array}$ & Brucellosis \\
\hline Pig & H1N1 virus & Swine flu \\
\hline Pig, cow, buffalo & $\begin{array}{l}\text { Taenia solium (pork tape } \\
\text { worm) } \\
\text { Taenia saginata (beef } \\
\text { tapeworm) }\end{array}$ & $\begin{array}{l}\text { Tapeworm } \\
\text { Taenia cysticercosis } \\
\text { Taenia } \\
\text { neurocysticercosis }\end{array}$ \\
\hline Pet dogs and cats & Giardia lamblia & Giardiasis \\
\hline Apes and sooty mangabey monkeys & HIV & HIV / AIDS \\
\hline
\end{tabular}

Sources: (Park, 2009, pp. 215-260)

\section{DISCUSSION}

Diversified communities of Nepal share their happiness and grief through several cultural and ritual ceremonies. Community farming, sharing goods, growing and rearing crops and livestock according to their annual consumption are some common traditional practices and characteristics of ethnic communities. Animal husbandry is more common in rural than urban communities, where they use animals for numerous purposes. The common reasons for rearing animals in Nepalese Communities are to sustain livelihood or fulfill spiritual or ethnomedical purposes. However, interaction with animals needs to be safe to prevent zoonotic diseases.

\section{Animals and ethnocultural practices}

Culture and religion are strongly associated with health behaviours, especially in underprivileged, poor, and illiterate communities. Thirty-four percent of the population is still illiterate in Nepal (CBS, 2011). Most of them belong to agrarian communities that still practice several superstitions.

Based on caste, Chhetri (16.60\% of the total population), Brahmin (12.18\%), Thakuri (1.61\%), and Dalit (Damai, Kami, \& Sarki, 7.94\%) who follow similar culture and festivals, commonly use cows, cow milk, dung and urine for their religious ceremonies. They sacrifice goats, sheep, 
and pigeons to worship the Goddess. Newars (5.81\%) commonly use poultry, Poultry eggs, goats, and buffalo in their cultural festivals. They rear them in their households. However, they are hardly cautious about zoonoses like bird flu, brucellosis, salmonellosis, etc., common in those animals.

Magar (7.12\%) commonly used pigs and poultry in their socio-cultural and religious ceremonies, despite them being the sources of tapeworm and swine flu. Joshi, Maharjan, Johnsen, Willingham, and Sharma (2004) showed ante mortem detection of T. Solium infection of pigs, $32 \%$ (136/419) of pigs noticed positively by lingual test while $24 \%(48 / 201)$ were found serologically positive in Syangja district. Swine flu, an equally important zoonotic disease, is also pig-borne, a relatively new strain of influenza, whose first pandemic outbreak took place in 2009 from Mexico and was reported with 25,214 cases (Adhikari, Shakya, Upadhyay, KC, \& Dhungana, 2009). Based on the literature, ethnic groups rearing pigs and consuming pork are more vulnerable to acquiring zoonoses because of unsafe food habits. Gurungs (1.97\%) also celebrate their festivals with many livestock like; buffalos, goats, poultry, and sheep. Thakali $(5.81 \%)$ is the ethnicity that mainly lives in Mustang and is well-known for its culture of drinking fresh blood of alive yak by draining it from the blood vessels of its neck. However, they are unaware of any possible transmission of zoonoses in case the yaks are infected.

Tharu, Kumal, Majhi and Darai $(6.56 \%, 0.46 \%, 0.32 \%$ and $0.06 \%)$ respectively of total population) are some of the ethnic groups whose livelihoods are dependents on various animals used for different socio-cultural purposes. They celebrate Dashain, Tihar, Maghi and worship their Kul Devata, perform Devi puja, Bhaakal puja, Ban Devi puja with the sacrifice of several animals like; pigs, hen, sheep, pigeon but are not aware of the health condition of livestock and the risk of zoonoses posed by them.

Ethnic groups of Eastern Hill are well-known for their linguistic distinction and cultural heritage., Rai and Limbu communities (2.34\% and $1.46 \%$ of the total population respectively), who are Kirats by religion, also use animals to celebrate their ceremonies like Naming, marriage, Uddhauli, Uvaulli, Kul puja, Bhimsen Puja, Prakriti puja by sacrificing pigs, hens, and buffalos.

Teli $(1.4 \%)$ is the ethnic community of eastern Terai, which follows Hinduism and celebrates several ceremonies with the use of goat and pigeon. Kul puja, Bhakaal puja, Dashain, Tihar, Naming, Mundan are the common festivals they celebrate by sacrificing the animals. However, like other ethnic groups, they too hardly discuss zoonotic risks. So, based on this survey, we can conclude that people of all ethnicities have close interaction with animals for diverse sociocultural practices; however, poor knowledge on safe handling of animals and their products may impose more significant risks of acquiring zoonoses.

\section{Animals and religious practices}

Culture and religion jointly influence and determine the behavior of people. According to census 2011, the majority of the population in Nepal belonged to Hinduism $(81.3 \%)$ while Buddhists (9\%), Muslims (4.4\%), Kirats (3.1\%), Christians (1.4\%), and others constitute the remaining population. Hindus are rich in their cultural practices and use cow and their products, especially urine, milk, and dung, during all religious customs from 'womb to tomb.' Some castes following the Hindu religion sacrifice goat, sheep, hens, ducks, pigeons, buffalos, and pigs for different purposes. On the other hand, Buddhists avoid sacrificing animals, and ethically, they never consume flesh. However, due to the diversification of communities and the effects of 
enculturation and acculturation, some ethnic groups follow Buddhism and Hinduism and sacrifice animals. But radical Buddhists who practice austere life believe in keeping peace among living creatures, including animals. Muslims also sacrifices goat, sheep, and buffalos in their religious festivals like Bakrid. However, Christians do not sacrifice animals to worship their God.

Therefore, religiously, Hindus and Muslims are in close contact with animals and may risk acquiring zoonotic infections while celebrating several ceremonies due to inadequate knowledge about the safe handling of animals and their products.

\section{Animals and livelihood}

Nowadays, the paradigm of animals and livelihood has been shifting from traditional to marketoriented commercial farming (Bagale \& Adhikari, 2019). People have adopted animal farming as a profession, which also contributes to combating hunger and protein-energy malnutrition. However, they are not aware of its risks. With the intensified and diverse use of animal products, the risks of several emerging and re-emerging fatal zoonoses like Ebola, SARS, and COVID -19 are increasing.

\section{Animals and ethnomedicinal practices}

Despite studying the ethnomedicinal practices of several ethnic groups related to animals, many have not yet been much conscious. In this study, we reviewed some ethnomedicinal practices of eleven ethnic groups of Nepal. We found that animals and their products are still prevalent among most ethnic groups to alleviate human ailments.

Timilsina and Singh (2014) explore that, Balami (who belongs to the Newar community) followed several animal-related ethnomedicine practices to human illness. They used jackals' meat for chronic headaches and rheumatism, and arthritis was treated with the meat of fox. They prescribed poultry eggs for dysentery. Furthermore, in rheumatism, they used bile and fat of bear. Also, in Assam, India, malaria is treated with the bile of bears (Verma, Prasad, Rongpi, \& Arjun, 2014). In Arunachal Pradesh, it is used for stomach pain, headache and reduce labor pain (Jugli, Chakravorty, \& Meyer Rochow, 2019). This variation indicates that the same animal products were traditionally used for various ethnic groups worldwide for different health problems.

Lohani (2011) explores the ethnomedicinal practices of Magars in central Nepal related to different animals. They prescribed Battais' meat (Common quail) for asthma and the loss of sexual desire. They prescribed the meat of sparrow. Egg of duck was used for weak eyesight. They also used soup of pigeon meat for asthma and jackals' wine for asthma and arthritis. Rhino's urine which is not readily available in most Nepal is collected and stored for a long time to treat TB, asthma, and gastritis. People who suffered from cataracts and measles used meat and milk of black goat and sheep's fat for burnt and cracked skin. However, in the central part of Nepal, people practice bats' meat to treat asthma and tuberculosis (Adhikari, Bhattari, Rokaya, \& Thapa 2020).

Compared with Karbi Anglong's study in India, we found similar practices in which people still rely on traditional medicines for their primary health care. The fat of buffalo, pig and domestic fowl was applied for relief from pain, donkey milk for whooping cough (fresh milk). Foxs' fat for rheumatism (applied locally), the bile of porcupine used for stroke, pigs' fat for furunculosis, cow's urine (fresh urine) for anemia, and bear of bile for malaria. Similarly, sheep's fat was used 
for torsion and rheumatism, Monkey's raw blood for tuberculosis, liver of fox used for rheumatism and bronchitis, the flesh of house mouse (rat) for cold and skin disease, Rabbit heart for preventing miscarriage and human urine was used for conjunctivitis and skin disease (Verma et al., 2014).

Paudyal and Singh (2014) mention Migratory Tangbetons living in Pokhara. The latter are using several animals and their products for many human ailments. They explore that horn, meat, and yak blood are used for indigestion, diarrhea, fever, and generating body energy. Those types of practices are also found in the Sherpa community of Solukhumbu, Nepal, where people drink the blood of yak and nark during Lhosar (Buddhist New Year) while the Thakali people in Mustang, Magdi, and other drink fresh blood of yak in order to cure digestive problems, gastritis and hypertension (Joshi, Maharjan, Johnsen, Willingham, \& Sharma, 2010).

Migratory Tangbetons practiced goat meat consumption for body pain and generating heat, cow urine for joint pain and water deposition inside the joints, sheep meat for rheumatism, meat and fat of deer for heavy bleeding, menstrual irregularities, and sinusitis. Jackal meat was used for rheumatic arthritis and vulture meat for thyroid disease. They also prescribed donkey's blood, meat, and nail for joint pain, diarrhea, and water deposition in the human body, respectively. Not only meat and blood, but these people also used the stool of pigeons to treat abscesses and human urine for conjunctivitis.

Tamang and Singh (2014) studied Lapcha ethnicity in eastern Nepal about animal-related ethnomedicine practices. They found that if people have boiled in their skin, it could be treated by the powder of cow's and buffalo's tooth, while bile of buffalos was used for asthma. They used cow milk for body ache and backache, hoof, and fetus of deer in the case of mushroom poisoning. They also used dogs' brains to treat rabies patients. The meat, bone, and hide of the jackal were indicated for tuberculosis and rheumatic fever. Elephant' bone was useful for treating internal eczema and the stomach of porcupine for asthma patients. They even applied snake bile on cut wounds and fish fat on burn wounds.

We found similar ethnomedical practices in Gibbon Wildlife Sanctuary Assam, India, where mongoose meat was boiled and prescribed for cancer, asthma, and rabies patients. Squirrel meat for asthma, cow milk for skin cancer and chronic asthma, cow urine for epilepsy, ash of buffalo horn for pre-menstrual pain, the smoke of deer horn used for piles, human urine was given as a drink for senseless patients and applied locally on wounds as an antiseptic (Borah \& Prasad, 2017).

Lohani (2011) also studied ethnomedicine practices of animals in Jirel in central Nepal and observed that people consumed sparrow's meat to improve memory and sexual power. Danphe, the national bird of Nepal, was implicated in heart problems. The cooked flesh of crow was used for body ache, while the alimentary canal of porcupine was used in asthma. They also used bile juice of Himalayan black bear to treat malaria, jaundice, heart problems, and fat used in sprains, burn, wounds, and boils. Very interestingly, they used the stool of a "Black Dog" as an antidote for poisoning.

Jugli et al. (2019) also found similar zoo therapeutic in Tanqsa and Wancho of eastern Arunachal Prades, India, where bear bile was used for stomach pain and headache and to reduce labor pain. Black bear's gallbladder and bile were used for malaria, body and joint pains, cough, colds, toothache, TB, and burn cases. In addition, fox flesh (fresh or cooked) was used for body and joint pain, as an energy booster for weak persons and pregnant women, dog liver and 
gallbladder or bile as an antidote for a dog bite, tiger/leopard's fat for burn, blood of hoary bamboo rat for liver cirrhosis and freshly cooked rat meat for scabies and allergy. The smoke and dried flesh of the squirrel's urinary bladder were used to treat gallbladder and kidney stone pain. Dangerously enough, goats' excreta (fresh or dried) was used on cuts, burns, and even on infants' stumps of umbilical cords.

Similarly, Lohani (2010b) also explored the ethnomedicine practices by the Tamang community in central Nepal. They used the cooked meat and fat of snakes for weak vision and also believed to cure cancerous wounds. Fat of chicken was applied on sprains and strains. The bile of buffalos was used for gastritis. The soup of boiled alimentary canal of porcupine was used for chronic asthma.

Poudel and Singh (2016) conducted a study on the Darai community in Chitwan, where the egg of Huttityan (bird commonly found in river banks) was used to treat typhoid fever. The egg blood and meat of wild hens were used for eczema, menstrual disorder, and cold, respectively. The bone of the vulture was used in fractures. They even used urine, sweat, and hoof of horse for alcohol addiction and typhoid fever, and rabbit meat for intestinal pain.

Quave, Lohani,Verde, Fajardo, \& Pieroni (2010) explore the animal practices by Majhi communities in the central mountainous region of Nepal. They are usually scattered along the river banks and have adopted fishing and boating as their profession. Majhi people also followed several ethnomedicine practices during their sickness. They used cooked flesh of Nilkantha (bird) as an antioxidant, fat of chicken for burns, while bile and blood of deer prescribed for infertility women. Also, sheep's urine was used for otitis (earache), the bile of sloth bear for hydrocele, and liver and gallbladder of monkeys for adequate nutrition in TB patients. Likewise, the bile of Asian elephant was used in gastritis and soup (boiled alimentary canal) of porcupine used for asthma and patients of urine retention.

Nepal has diversified and mixed communities and their socio-cultural or ethnomedicinal practices are also influenced by each other. Based on several research findings, we have concluded that most of the ethnicities in Nepal follow any type of ethnomedicinal practices during their sickness. Some of them depend on herbs while the others were the by-products of animals. Their mechanism of action based on scientific studies are unknown. However, these practices have been followed for a long time ago, thus demanding a controlled study showing the need to create awareness about the importance of conserving endangered wildlife. The literature shows that exposure to animals without any precautions may transmit zoonoses. Therefore, the person who has a close interaction with animals for different purposes needs to be aware of the threats of possible zoonoses.

\section{Animals as sources of different zoonotic diseases}

Out of about 1415 species as pathogenic to humans, $61 \%$ may be categorized as zoonotic. Of the 175 newly emerging pathogens in humans, $75 \%$ are listed as zoonoses (Tylor, Latham, \& Woolho, 2001). A great number of wild and domestic animals are important reservoirs for many of these zoonotic pathogens. Different types of zoonotic agents can infect people along with animals.

People are rearing animals in their households for multiple purposes, but most have poor knowledge about zoonoses. Health educators need to disseminate zoonoses-related information to the entire population. There are lots of zoonoses acquired from livestock, zoo, or wild animals, which we cannot point out in a single study or involving a few minds. However, it is better to know about the common zoonoses and their possible host characteristics to the people who are regularly exposed to animals by the cost-effective approach of health education. 


\section{CONCLUSION}

People are rearing animals in their households for multiple purposes. Many zoonoses are acquired from livestock, zoo, or wild animals. However, we cannot point them out in a single study or involved by a few researchers. Ethno-medical, ethnocultural, religious, or ritual practices of ethnic groups increase intimacy with animals vulnerable to acquiring zoonotic infection. Hence, we need to educate these people regarding zoonoses and possible preventive measures. Government and international organizations working in this sector should conduct laboratory research for validation and a medical indication of animal products and carry out several cost-effective interventional activities like health education and orientation programs for vulnerable communities.

\section{REFERENCES}

Adhikari, B.R., Shakya, G., Upadhyay, B. P., KC, K. P., \& Dhungana, G. R. (2009). Outbreak of pandemic influenza A/H1N1 2009 in Nepal. Virology Journal, 8(1): 1-8. doi: https://doi.org/10.1186/1743-422X-8-133.

Adhikari, J. N., Bhattari, B. P., Rokaya, M. B., \& Thapa, T. B. (2020). Ethnomedicinal uses of Vertebrates in Chitwan- Annapurna Landscape, Central Nepal. PLoS ONE 15(10): e0240555. doi: https://doi.org/10.1371/journal.pone.0240555

Adhikari, S. (2015). Contribution of agriculture sector to national economy in Nepal. The Journal of Agriculture and Environment, 16: 180-187. doi: https://doi.org/10.3126/aej.v $16 \mathrm{i0.19851}$

Bagale, K. B., \& Adhikari, R. (2019). Risk of Zoonoses among livestock farmers in Nepal. Journal of Health Promotion, 7: 99-110. doi: https://doi.org/10.3126/jhp.v7i0.25520

Bagale, K. B., Gaire, B., \& Adhikari, R. (2020). Zoonotic risk for pet owners in Kathmandu, Nepal. Global Journal of Medical Research, 20(2): Retrieved from 1-13.

https://www.medicalresearchjournal.org/index.php/GJMR/article/view/2173/2062

Berger, J. (1980). 'Why Look at Animals?" About looking, New York: Pantheon, pp. 1-28.

Borah, M. P., \& Prasad, S. B. (2017). Ethnozoological study of animals based medicine used by traditional healers and indigenous inhabitants in the adjoining areas of Gibbon Wildlife Sanctuary, Assam, India. Journal of Ethnobiology and Ethnomedicine, 13(1):39. doi: https://doi.org/10.1186/s13002-017-0167-6

CBS. (2012). National Population and Housing Census 2011 (National Report), Vol. 01. Central Bureau of Statics, Kathmandu.

Green News. (2021). How animals shaped the evolution of humans. Retrieved from https://greennews.ie/how-animals-shaped-the-evolution-of-humans/\#: :text=Dom esticating $\% 20$ plants $\% 20$ and $\% 20$ animals $\% 20$ gave, lifestyle $\% 20$ to $\% 20$ settled $\% 20$ living $\% 20$ patterns

Joshi, D. D., Maharjan, M., Johnsen, M. V., Willingham, A. L., \& Sharma, M. (2004). Taeniasis / Cysticercosis Situation in Nepal. The Southeast Asian Journal of Tropical Medicine and Public Health 35:252-258.

Joshi, S., Shrestha, L., Bisht, N., Wu, N., \& Long, R. (2010). Ethnic and Cultural Diversity amongst Yak Herding Communities in the Asian Highlands. Sustainability, 12(3): 957. doi: https://doi.org/10.3390/su12030957. 
Julgi, S., Chakravorty, J., \& Meyer Rochow, V. B. (2019). Zootherapeutic uses of animals and their parts: an important element of the traditional knowledge of the Tangsa and Wancho of eastern Arunachal Pradesh, North-East India. Environment, Development and Sustainability, 22:4699-4734. doi: https://doi.org/10.1007/s10668-019-00404-6

Lohani, U. (2010a). Man animal relationship in central Nepal. Journal of Ethnobiology and Ethnomedicine, 6(1). doi:31. https://doi.org/10.1186/1746-4269-6-31

Lohani, U. (2010b). Eroding Ethnozoological Knowledge among Magars in Central Nepal. Indian Journal of Traditional Knowledge, 10(3), 466-473.

Lohani, U. (2011). Traditional Uses of Animals among Jirels of Central Nepal. Studies on Ethno-Medicine, 5(2): 115-124. doi: https://doi.org/10.1080/09735070.2011.11886398

Park, K. (2009). Park's textbook of preventive and social medicine $\left(20^{\text {th }}\right.$ ed.). Jabalpur, India: $\mathrm{M} / \mathrm{s}$ Banarsidas Bhanot.

Paudyal, R., \& Singh, N. B. (2014). Ethno medical uses of animals and plant among the migratory Tangbetons of Pokhara Nepal. Journal of Institute of Science and Technology, 19(1),145-149.doi: https://doi.org/10.3126/jist.v19i1.13840

Poudel, M., \& Singh, N. B. (2016). Medical Ethnobiology and Indigenous Knowledge System Found in Darai Ethnic Groups of Chitwan Nepal. Journal of Institute of Science and Technology. 21(1):103-111. doi: https://doi.org/10.3126/jist.v21i1.16061

Poudel, M., \& Singh, N. B. (2016). Teaching (with) Medical Ethnobiology: Indigenous Knowledge System Found In Raji People of Western Nepal. International Journal of Multidisciplinary Perspectives in Higher Education, 1(1): 47-62. Retrieved from https://www.ojed.org/index.php/jimphe

Quave, C. L., Lohani, U., Verde, A., Fajardo, J., \& Pieroni, A. (2010). A Comparative Assessment of Zootherapeutic Remedies from Selected Areas in Albania, Italy, Spain and Nepal. Journal of Ethnobiology, 30(1): 92-125. doi: https://doi.org/10.2993/0278-0771$\underline{30.1 .92}$

Tamang. P., \& Singh, N. B. (2014). Medical ethnobiology and indigenous knowledge system of Lapcha of Fikkal VDC of Illam, Nepal. Journal of Institute of Science and Technology, 19(2): 45-52. doi: https://doi.org/10.3126/jist.v19i2.13851

Taylor, L. H., Latham, SM., \& Woolhouse, M. (2001). Risk factors for human disease emergence. Philosophical Transactions of the Royal Society B: Biological Sciences 356(1411): 983-989. doi: https://doi.org/10.1098/rstb.2001.0888

Timilsina, S. H., \& Singh, N. B. (2014). Ethnobiology and Indigenous Knowledge about Medicinal Animals and Plants in the Balami Ethnic Group in Nepal. Journal of Institute of Science and Technology, 19(2): 79-85. doi: https://doi.org/10.3126/jist.v19i2.13857

Verma, A., Prasad, S., Rongpi, T., \& Arjun, J. (2014). Traditional healing with animals (zootherapy) by the major ethnic group of Karbi Anglong district of Assam, India. International Journal of Pharmacy and Pharmaceutical Science, 6(8): 593-600. Retrieved from https://innovareacademics.in/journals/index.php/ijpps/article/view/2763/pdf_115 